\title{
Lise Öğrencilerinde Hayatın Anlam ve Amacı ile Değer Yönelimleri Arasındaki İlişki
}

\author{
Arş. Gör. Abdullah TANRIVERDi ${ }^{*}$ Dr. Öğr. Üyesi Mustafa ULU**
}

Atıf / @-- Tanrıverdi, A. ve Ulu, M. (2018). Lise Öğrencilerinde Hayatın Anlam ve Amacı ile Değer Yönelimleri Arasındaki İlişki, Çukurova Üniversitesi Ilahiyat Fakültesi Dergisi, 18 (2), 1198-1234.

Öz- Bu çalışmada lise öğrencilerinde hayatın anlam ve amacı ile değer yönelimleri arasındaki ilişkiyi incelemek amaçlanmıştır.

Araştırmanın teorik çerçevesi olarak Viktor Emil Frankl'ın insanın en temel güdüsünün anlam istemi oluşu fikrinden hareketle ortaya koyduğu hayatın anlam ve amacına dair görüşleri ile Shalom $H$. Schwartz'ın değer yönelimi hakkındaki yaklaşımları temel alınmıştır. Araştırmada Kayseri ilindeki 3 farklı devlet lisesinde öğrenim gören 507 öğrenciden nicel yöntemle veri toplanılan araştırmada katılımcılar tesadüfi olmayan örnekleme yöntemlerinden "uygun/kolayda örnekleme" yöntemi yardımıyla seçilmiştir. Katılımcıların \%30'unu (n=150) erkek öğrenciler, \%70'ini ise (n=357) kız öğrenciler oluşturmaktadır. Veriler, Crumbaugh ve Maholick tarafından geliştirilmiş ve Türkçeye Ferdi Kıraç tarafından uyarlanmış olan Hayatın Amacı Ölçeği ile Schwartz ve arkadaşlarının geliştirdiği, Demirutku ve Sümer tarafından da Türkçeye uyarlanmış olan Portre Değerler Anketi ile toplanmışlardır. Verilerin analiz edilmesinde betimsel istatistik tekniklerinden ortalama ve standart sapma değerleri; çıkarımsal istatistik tekniklerinden iki ortalama arasındaki farkı tespit etmek amacıyla bağımsız gruplar t-testi; değişkenler arasındaki ilişkileri belirlemek amacıla ise Pearson Momentler Çarpımı Korelasyon tekniği ve Regresyon analizi kullanılmıştır. Analiz sonuçlarına göre katılımcıların değer yönelimindeki ortalama puanının 4,63; hayatın amacındaki ortalama puanlarının ise 3,40 olduğu; değer yönelimlerinde en yüksek ortalamayı 4,94 puan ile öz-yönlendirme, en düşük ortalamayı ise 3,90 puan ile güç faktöründe elde ettikleri; hayatın amacında en yüksek ortalamaya 3,89 ile anlam ve amaç faktöründe, en düşük ortalamaya ise 2,91 ile hayat kalitesi faktöründe sahip oldukları; iyilikseverlik ve evrenselcilikte kızların, güç faktöründe ise erkeklerin ortalama puanlarının anlamlı olarak daha yüksek olduğu; hayatın amacı ölçeği toplam puanı ile başarı, hazcılık, uyarılma, özyönlendirme, evrenselcilik, iyilikseverlik, geleneksellik, uyma, güvenlik değerleri arasında pozitif yönde güçlü bir ilişki olduğu; değer yönelimi ölçeği

\footnotetext{
* Erciyes Üniversitesi İlahiyat Fakültesi Din Psikolojisi Anabilim Dalı, e-posta: tanriverdi@erciyes.edu.tr

** Erciyes Üniversitesi İlahiyat Fakültesi Din Psikolojisi Anabilim Dalı, e-posta: mustafaulu@erciyes.edu.tr
} 
toplam puanı ile ise hayatın amacı ölçeğindeki tüm faktörlerin pozitif yönde güçlü bir ilişkilerinin olduğu belirlenmiştir. Regresyon analizi neticesinde ise güç, hazcılık, geleneksellik ve güvenlik değer yönelimlerinin hayatın amacını anlamlı olarak \%13 oranında açıkladığı görülmektedir.

Anahtar sözcükler- Din Psikolojisi, Hayatın Anlam ve Amacı, Frankl, Değer Yönelimi.

\section{$\S \S \S$}

\section{Giriş}

İnsanlığın ilk dönemlerinden itibaren gerek dinler gerekse felsefe "hayatın anlamı ve amacının ne olduğu" sorusuna cevap vermeye çalışmışlardır. Dinler söz konusu sorunun cevabını genellikle insanüstü temellerle izah etmeye çalışmışlardır. Onlara göre hayatın amacı bulmada din ve onun sunduğu yaşam tarzı mihenk taşıdır. Dinin anlamla ilişkisi bağlamında Allport, dini duygunun kişiye varlığıyla anlamlı bir ilişki sunan bütünsel bir tutum olduğunu ve kişi için derin ve köklü anlamları kuşatan bir mahiyet arz ettiğini ifade eder (Allport, 2016, s. 12). Ayrıca dinin insanın hayatına yön veren, bütüncül bir hayat felsefesi sunduğu (Sezen, 2009, s. 191), ölüm sonrası ahiret hayatı düşüncesi ile insan hayatına önemli bir anlam boyutu kattığı (Özarslan, 2000, s. 306), anlam arayışının fıtrî olduğu (Serinsu, 2012, s. 708), insanın metafizik intiyaçları olduğu ve ancak bunlar karşılandığında hayatının anlam kazanacağı (Selçuk, 1998, s. 185), bu metafizik intiyaçların semavî dinlerde kabul gören İbrahim peygamberin varoluşsal sorgulamalarında somut örnek bulduğu (Çapcıoğlu \& Yürük, 2011,30-31), dünyada gerçekleşen hadiselerde tanrının bir takım amaçlarının olduğu (Ćufta, 2016, s. 114) gibi hususlar anlam arayışı konusu etrafında ele alınmaktadır. Felsefe ise varoluşsal sorunlar kapsamında ele aldığı "hayatın anlam ve amacının" ne olduğu meselesine, yöntemi gereği insan aklını referans alarak cevap arama yoluna gitmiştir. Felsefe tarihine bakıldığında Sokrates gibi büyük düşünürlerin "insanın nasıl yaşaması gerektiği” sorusuna odaklanmaları, yakın dönem filozoflarından Kierkegaard, Nietzsche, Heidegger, Sartre ve Camus gibi birçok filozofun varoluşsal sorunlara eğilmeleri, bunların felsefî açıdan halen güncel ve ilgi çekici olduğunu ortaya 
koymaktadır. Yine, Cumhuriyet dönemi mütefekkirlerinden Nurettin Topçu'nun "Var Olmak" isimli eseri de söz konusu meselelerin birbirleriyle alakalarını ve taşıdıkları önemi göstermesi açısından önem arz etmektedir.

Psikolojik açıdan meseleye bakıldığında daha çok varoluşçu psikoloji okullarının bu konuları ele aldıkları görülmektedir. Söz konusu okullar, insan psikolojisinde anlam konusunun önemine dikkat çekerek psikolojik sağlık için anlamın önemine vurgu yapmaktadırlar. Bu psikologlar arasında Carl Rogers, Abraham Maslow, George Kelly, Otto Rank, Rollo May, Viktor Emil Frankl ve günümüzün önde gelen psikologlarından Irvin Yalom gibi isimleri saymak mümkündür. Varoluşçu psikologların bazıları özellikle hayatın anlamı konusunda gözlem yapabilme ve düşünme fırsatı bulabilecekleri zor hayat tecrübeleri yaşamışlar ve bu konunun önemini kendileri de müşahede etmişlerdir. Bunlardan Rollo May, verem tedavisi gördüğü sanatoryumda hayatta kalma mücadelesi verdiği dönemde çevresindeki diğer ölümcül hastaları gözlemlemiş ve hastalığını kabullenenlerin zayıflayıp ölürken, mücadeleye devam edenlerin hayatta kalma intimalinin yükseldiğine şahit olmuştur. Kendisi hasta yatağında "The Meaning of Anxiety" isimli kitabını kaleme almış ve bu yolla hayata tutunmuştur. Bir diğer önemli varoluşçu psikolog bu çalışmada esas alınacak olan logoterapinin kurucusu Viktor Frankl'dır. Gençliğinde hayatın anlamı sorununa yoğunlaşmış olan Frankl, ilk önce Nazi baskısından dolayı anne karnındaki bebeğini kaybetmiş ("Duyulmayan Anlam Çığlığı" isimli eserini kaybettiği bu evladına ithaf eder), daha sonra Nazi kamplarına alınan Frankl'ın kendisi dışında bütün ailesi kamplarda ölmüştür. Kendisi de kampta kaldığı süre boyunca çeşitli acılar yaşasa da Nazilerin el koyduğu "The Doctor and The Soul" kitabını yeniden yazma amacının kendisini hayatta tuttuğunu ifade etmektedir (Frankl, 2016, ss. 118-119). Esaretten kurtulduktan sonra kamp tecrübelerini ve logoterapinin temel ilkelerini ele aldığı "Insanın Anlam Arayışı" kitabını yazmışıı. Varoluşçu psikologların bu gibi katkıları her ne kadar konuyu psikolojik anlamda öne çıkarmışsa da psikolojinin hâkim ekolü olan davranışçılığın etkisini aşmaya yeterli olamamıştır. Hatta ilginç bir şekilde 
birçok psikoloji tarihi kitabında Viktor Frankl'ın ismi dahi zikredilmemektedir. Ancak varoluşsal konular üzerine çalışan transpersonel (ben-ötesi) psikoloji gibi okullar söz konusu konularda çalışmalarını sürdürmektedir.

Değerler ise eskiden beri hem dinlerin hem de etik felsefesinin ilgisini çeken konulardan biri olması hasebiyle değerlerin niteliği, önemi, temel değerlerin neler olduğu ve bunların yansımaları gibi konuya dair birçok mesele ele alınmış ve ciddi bir birikim meydana getirmişlerdir. Meseleye toplumsal açıdan bakılırsa değerlerin daha çok gelenekler ile birlikte nesilden nesile aktarıla gelen bir toplumun hareket, davranış ve düşünüşünü şekillendiren önemli toplumsal dinamikler olarak işlev gördüklerini söylemek mümkündür. Modern döneme gelindiğinde ise bir takım teknik ve teknolojik imkânların artması sebebiyle bilginin dolaşımı artmış, eski gelenekler ve onlarla birlikte taşınan değerler ciddi sorgulamalara tabi tutulmuş, söz konusu durum geleneksel anlamda aktarıla gelen değerlerin de önemli ölçüde zayıflamasına yol açmıştır. Ayrıca değerler yavaş yavaş modern bilimsel araştırmalara konu edilmeye başlanmıştır. Psikolojinin insanın sadece ruhsal hastalıklarının tedavisi veya durum tespiti yapmasının yetersiz olduğu ve psikolojinin insanın olumlu yanlarını da araştırması gerektiği tezinden hareket eden pozitif psikoloji ekolü bu bağlamda değerleri bilimsel araştırmalarına konu eden disiplinlerdendir. Pozitif psikolojide değer araştırmalarına öncülük eden isim ise Amerika'da yaptığı çalışmalar ve geliştirdiği Değer Yönelimi Envanteri ile Rokeach'tır. Rokeach'ın birçok dile çevrilen çalışmalarının ardından, Shalom H. Schwartz ile değer araştırmalarının daha ileri bir düzeye taşındığı ifade edilebilir.

$\mathrm{Bu}$ çalışmada araştırma konusu edilen lise öğrencileri açısından meseleye bakıldığında modern dönemle birlikte Türkiye'nin oldukça köklü birtakım toplumsal ve kültürel değişmeler yaşadığı ve bu değişen toplumsal rol beklentilerinden önemli oranda etkilenen gençlerde bu durumun ruhsal bir gerilim ve arayışa neden olduğu söylenebilir (Hökelekli, 2016, ss. 74-75). Bulundukları gelişim dönemi gereği kimlik oluşturma intiyacı içinde olan 
gençlerin bu çerçevede kendi anlam ve değer dünyalarını inşa etmeye çalıştıkları ifade edilebilir (Erikson, 1968, s. 26; Hökelekli, 2016, ss. 74-75). Söz konusu gidişatın çağımızda bir tür karmaşaya yol açtığı birçok düşünür tarafından sezinlenmiş ve çağın insanının bir çeşit "anlam bunalımı" yaşadığı ifade edilmiştir. Son dönemde lise öğrencilerinin deizme kaydığı yönündeki iddiaların bu minvalde değerlendirilmesi mümkün gözükmektedir. Bu ise lise öğrencilerinin hayatın anlamı ve değer yönelimleri konusundaki durumlarını daha önemli bir hale getirmektedir.

Bütün bunlardan hareketle bu çalışmada literatürdeki gelişmeler de göz önünde bulundurularak lise öğrencilerinde hayatın anlamı ile değer yönelimleri arasında herhangi bir ilişki olup olmadığı; varsa nasıl bir ilişki olduğu nicel araştırma tekniklerinden istifade edilerek ortaya konmaya çalışılacaktır. Bu açıdan öncelikle hayatın anlamı ile değer yönelimi konularında kavramsal bir çerçeve çizilecek, daha sonra çalışmaya dair lise öğrencileri üzerinde gerçekleştirilen istatistiksel verilere yer verilecek, son olarak da elde edilen veriler literatür temelli olarak değerlendirilmeye çalışılacaktır.

\section{Hayatın Anlamı}

Anlam kelimesi, çeşitli sözlüklerde bir kelimeden, bir sözden, bir davranış veya olgudan anlaşılan şey, bunların hatırlattığı düşünce veya nesne, mana, meal, fehva ("Türk Dil Kurumu”, t.y.); bir kelimenin veya kelime dizisinin veya bir kavramın, işaretin veya sembolik eylemin bilişsel veya duygusal önemi (VandenBos \& American Psychological Association, 2015, s. 631); kişinin herhangi bir olay, nesne, varlık veya olgunun şuuruna ermesi ve ona dair bilgileri edinmesi süreci (Hançerlioğlu, 1993, s. 35) gibi çeşitli şekillerde tanımlanmıştır. Anlam konusundaki en iyi yapılmış tanımlardan birisi Reker ve Wong'a aittir. Buna göre anlam, "bireyin varlığındaki düzen, tutarlılık ve amacı fark etmesi, değerli amaçların peşinde koşması ve bunların ardından gelen tatmin duygusunu hissetmesidir" (Reker \& Wong, 1983, s. 221; Ulu, 2018a, s. 167). 
Hayatın anlamı ise birçok psikoloğun ilgisini çekmiş bir konudur. Örneğin II. Viyana Ekolü olarak bilinen bireysel psikolojinin kurucusu meşhur psikolog Adler, bu konuda "Yaşamın Anlamı" ve "Yaşamın Anlam ve Amacı" başlığını taşıyan iki önemli eser kaleme almıştır. İsmi geçen ikinci kitabında hiçbir insanın anlam olmadan yaşayamayacağını ifade eden Adler, kişinin anlamlı bir ilişki ağından teşekkül eden bir çerçeve oluşturarak hayata baktığını ve gerçeği de her zaman ona atfedilen anlam vasıtasıyla idrak ettiğini söyler (Adler, 2016, s. 7). Yine ona göre "hayatın anlamının ne olduğu" sorusu insanlıkla aynı yaştadır. Ayrıca Adler'e göre din de bu noktada insana ulvî hayat gayeleri veren önemli bir müessesedir (Adler, 2016, s. 16). Adler insanın daha hayatının ilk yılları olan bebeklikte dahi o dönemin imkânları nispetinde hayatın anlamına ulaşmaya çalıştığını ifade eder. Bunları kaydettikten sonra ilginç bir tespitte bulunan Adler, insanın hayatının ilerleyen dönemlerinde yaşadığı ıstırap ve meşakkatlerin temel sebebinin başından geçen hadiseler değil, yaşadığı söz konusu durumlara atfettiği anlamlar olduğunu ifade eder (Adler, 2016, ss. 17-19). Bütün bunlardan dolayı Adler, kişinin hayatına atfettiği anlamın tespitini o şahsın bütün kişiliğine ulaşmada anahtar mahiyetinde görür (Adler, 2016, s. 28).

Hayatın anlamı söz konusu edilince ilk akla gelen isim ise kuşkusuz logoterapinin kurucusu varoluşçu psikiyatr Viktor Emil Frankl'dır. Yunanca "logos" (anlam) kelimesinden hareketle "anlam terapisi" manasına gelen logoterapi yöntemini ortaya koyan Frankl ve takipçileri, Freud ve Adler'in ardından III. Viyana Ekolü olarak bilinmektedirler. Logoterapi'ye göre, kişinin hayatındaki esas belirleyici olan şey "anlam istemi"dir ve söz konusu anlam sadece bireyin bizzat şahsı tarafından tespit edilebilir, bundan dolayı da biriciktir (Frankl, 2016, s. 113). Logoterapistin görevi ise bireyin bu anlama ulaşmasında ona yardımcı olmaktır. Eserlerinde sürekli hayatın anlamı üzerinde duran Frankl, Nietzsche'nin şu sözüne oldukça büyük önem atfeder: "yaşamak için bir nedeni olan kişi hemen her nasıla katlanabilir." Bu bağlamda toplama kampı hatıralarından bahsederken Frankl, geleceğe yönelik bir amaç göremeyen insanların geçmiş yaşantılarına saplanmaya başladıklarını, böyle 
olunca hayatın bu insanlar için anlamını yitirdiğini ve dolasıyla da bu insanların kamp şartlarında ayakta kalmaya çalışmak yerine kendilerini çöküşe bıraktıklarını ifade eder. Bu çöküşü yaşamak istemeyenlerin ise Frankl'ın logoterapisinde olduğu gibi kampın zorluklarına direnebilmek için kendilerine geleceğe dair amaçlar koymak suretiyle içsel anlamda kuvvet topladıklarını belirtir. Söz konusu hadisede bedensel anlamda güçlü birçok esirin öldüğünü, buna mukabil hayata kendilerini bağlayacak bir anlam bulabilen, geleceğe dair ümitvar olan fiziksel anlamda zayıf birçok kişinin ise zorlu kamp şartlarında hayata tutunduğunu kaydetmesi de ayrıca ilgi çekicidir. Bu başarının insana özgü bir hususiyet olduğunun altını çizen Frankı, insan varoluşunun en olumsuz durumlara dahi tahammül etmesini sağlayan formülün bu olduğuna dikkat çeker. Dolayısıyla ona göre, kişinin kendisine ve geleceğine dair inancını ve gayelerini muhafaza etmesi hayati önem taşıyan bir meseledir (Frankl, 2016, ss. 87-92).

Hayatın insana yerine getirilmesi gereken vazifeler sunduğu kanaatini taşıyan Frankl'a göre hayatın anlamı, kişiden kişiye ve sürekli olarak değişim halindedir. Her insanın anlam durumu ise ona özgü bir mahiyettedir. Her bir ferdi diğerlerinden farklı kılan ve onun varoluşuna anlam katan benzersiz ve yegâne oluş hâlinin hem diğer bireylere duyulan sevgiye hem de yaratıcı faaliyetlere dönük olumlu bir etkisi söz konusudur. Biricik oluşunu fark eden insan, varoluşunun ona yüklediği mükellefiyetleri hakkıyla ifa ederek mesuliyetinin idrakine varacaktır. Böylece insan, hayatın amacını bulmuş olacağından nasıllara dayanabilecektir. Kamptaki kader arkadaşlarına yaptığı bir konuşmasında hayatın hiçbir zaman yitmeyen sonsuz bir anlamı olduğuna dikkat çeken Frankı, bu anlamın her türlü işkenceyi, acıyı, hatta ölümü bile kapsayan bir derinliği olduğunu ifade etmektedir. Frankl'a göre bu durumu inanç sahipleri daha iyi kavrayabilirler. Zira inanç sahipleri için bu hâlin tanrıyla olan bağlantısı sebebiyle acı ve ölüme derin bir anlam kattığı söylenebilir (Frankl, 2016, ss. 92-99). 
Frankl, hayatın anlamının ne olduğu meselesinde bu sorunun cevabının hem kişiden kişiye hem de zaman ve duruma göre değişkenlik arz ettiğini düşünür. Bundan dolayı ona göre daha öncelikli olan şey hayatın genel anlamından ziyade belirli bir zaman diliminde bireyin hayatının hususi anlamıdır. Her bireyin hayatında yaptığı iş, yüklendiği çaba harcamaya değecek bir görevi vardır ve hayatın soyut anlamından daha ziyade bu alana önem verilmelidir. Bu noktada sorumluluk bilincini öne çıkartan logoterapiye göre, hayat herkesi bir imtihana çeker, bu imtihanda yapılması gereken hayatın anlamının ne olduğunu sormak değil hayatın insana sunduğu soru(n)lara cevap üretmektir. Bu ise ancak sorumluluk bilinci ile mümkündür (Frankl, 2016, s. 123).

Frankl'a göre, insanın anlam arayışı tıpkı diğer arzuları gibi bastırılabilir. Böyle bir bastırmanın neticesinde de "varoluşsal engellenme" olarak adlandırılan durum ortaya çıkar. Varoluşsal engellenmeler kişinin nevroza yakalanmasına sebep olabilirler. Logoterapide bu tarz nevrozlara Yunanca'da zihin kelimesinin karşılığı olan "noos" dan mülhem olarak "noöjenik nevrozlar" denilmektedir. Noöjenik nevroz adı verilen hadise insanın içgüdüsel çatışmalarının yol açtığı klasik nevrozlardan farklı olarak, varoluşsal sorunlardan kaynaklanmaktadırlar. Söz konusu nevrozun oluşumunda en temel faktörlerden birisi belki de en önemlisi anlam arayışının engellenmesi durumudur. Bundan dolayı noöjenik nevrozlulara uygulanması gereken terapi yöntemi anlam eksenli psikoterapi yöntemi olarak ifade edilebilecek olan logoterapidir. Frankl'a göre, bir kişinin hayatın yaşanmaya değip değmeyeceğine dair kaygı duyması ve hatta bunun daha ileri bir boyuta geçerek ümitsizlik hâlini alması, varoluşsal bir anksiyete olmakla birlikte hiçbir şekilde bir ruhsal bozukluk anlamına gelmez. Böyle bir duruma hastalık teşhisi koyan doktor, arayış içindeki bir insanı ilaçlara hapsederek mahkûm edebilir. Hâlbuki bu durumda yapılması gereken şey bireyin varoluşsal bir gelişim krizi yaşadığını idrak ederek ona bu yolda yardımcı olmaya çalışmaktır (Frankl, 2016, ss. 114-118). Frankl, ruh sağlığının temel unsurları arasında gördüğü gerilim hakkında, ruh sağlığı açısından kişinin elinde olan ile elde etmeye 
çalıştığı şey arasında vücut bulan böyle bir gerilimin insanda yapısal olduğunu söyler. Anlamın sebep olduğu böyle bir gerilimin insanı ayakta tuttuğunu kaydeden Frankı, kitabını yeniden yazma işinin kampın hastalıklı ortamından kendisini korumasını buna örnek gösterir (Frankl, 2016, ss. 118-119). Logoterapinin bir diğer önemli kavramı ise varoluşsal boşluktur. Söz konusu boşluğun temelinde ise insanın engellenen anlam arzusu yer alır. Modern dönemin getirdiği en temel problemlerden olan bu his Frankl'ın kendi döneminde belirttiği verilere göre ABD’li öğrencilerde \%60 civarındadır. Modern insanın günlük hayatın telaşından uzaklaştığı tatil günlerinde veya emeklilik sonrası da insanın kendisiyle karşılaşma/yüzleşmeye maruz kalması sonrası bu boşluk hissi belirginleşmekte ve "Pazar günü nevrozu" örneğinde olduğu gibi çeşitli nevrozlarla kendisini aksettirmektedir. Veyahut da bu boşluk durumu kuvvet, para, haz gibi kılıflar halinde de ortaya çıkabilmektedir (Frankl, 2016, ss. 119-121).

Frankl, insan tabiatının fiziki, psikolojik ve manevi esaslar olmak üzere üç temelden teşekkül ettiğini düşünmektedir. Ona göre, bunlar arasında insanın manevi boyutu anlam arayışının meskeni konumundadır ve bu boyut Frankl'ın "öz-aşkınlık” şeklinde ifade ettiği aşkın yönüne vurgu yapar. Özaşkınlığı kişinin şahsı dışında bir varlığa bağlanma durumu olarak tasvir eder. Ona göre dindarlık da insanın öz-aşkınlığı ile ilgili bir hadisedir (Forsyth, 2017, ss. 327-329). Dinin anlam istemi hususunda çok temel cevaplar ürettiğini ve bu konudaki sorunların çözümünde çok önemli bir rolü olduğunu vurgulayan Frankl, bu yönüyle dinin Logoterapi açısından son derece kıymetli bir işlev gördüğüne dikkat çeker (Bahadır, 2011, s. 46). Akli yetilerle ulaşılamayan nihai bir anlamın mümkün olduğunu kaydeden Frankl, dini inancı olan hastalarda bu inancın sunduğu manevi kaynaklardan istifade etmenin, oldukça faydalı ve sağaltıma katkıda bulunabilecek önemli bir husus olduğunu işaret eder. Bu noktada dinin sunduğu anlamdan yararlanmanın olumlu neticeler ortaya koyabileceğini düşünmektedir (Frankl, 2016, ss. 133-134). Ayrıca insanın manevi bir bilinçdışı olduğunu ifade eden Frankl'a göre insanın bu boyutu itibariyle tanrıyla iletişim kurması imkân dâhilindedir. Söz konusu 
durumda bilinçdışı bir tanrıdan bahseden Frankl, bunun tanrının bilinçdışında bulunduğunu değil manevi bilinçdışı vasıtasıyla tanrı ile birey arasında bir bağ ve etkileşim tesis etmesinin olanaklı olduğunu söyler (Frankl, 2014, s. 56).

\section{Değerler}

Değer

kelimesi, sözlükte "nesne ve olayların bireysel ve öznel olarak önem taşıyan niteliği" (Hançerlioğlu, 1993, s. 102); "bir birey veya toplum tarafından iyi, arzu edilebilir veya önemli olana rehber olarak kabul edilen ahlaki, sosyal veya estetik ilke; bir şeye bağlı olan değer, yarar veya önem" (VandenBos \& American Psychological Association, 2015, s. 1146); "bir şeyi arzu edilir veya yararlı kılan özelliği veya niteliği; bir şeye bağlanan ruhsal enerji miktarı; belli bir toplumda, neyin iyi neyin kötü, doğru veya yanlış, arzu edilir veya arzu edilmez olduğu konusundaki ortak görüş ve standartlar" (Budak, 2017, s. 189) gibi çeşitli şekillerde tanımlanmıştır.

Psikolojide özellikle pozitif psikolojinin ilgilendiği bir konu olan değer konusunda en bilinen isimler Rokeach ve onun ardından kuramını daha ileri bir düzeye taşıyan Schwartz'dır. Rokeach değeri, "belirli bir davranış biçimi ya da varoluşun son şeklinin kişisel veya toplumsal açıdan varoluşun son durumuna ya da davranışın aksi ya da karşıtına tercih edilebilir olduğuna dair kalıcı bir inanç" olarak tanımlamıştır (Rokeach, 1973, s. 5). Geliştirdiği Rokeach Değerler Ölçeği ile Amerikan toplumunun değerlerini ölçme konusunda oldukça önemli bir konuma yerleşen Rokeach'ın ölçeği aralarında Türkçe'nin de olduğu birçok dile uyarlanmıştır (Ayvalıoğlu, 1989). Rokeach'ın halefi olarak değer araştırmalarını daha ileri bir boyuta taşıyıp, geliştiren Schwartz ise değeri "bireyin ya da diğer sosyal varlıkların yaşamında yol gösterici ilkeler görevini üstlenen, önemi açısından çeşitlenen, arzu edilen, durum dışı hedefler" olarak tanımlamaktadır (Schwartz, 1992, s. 4; 1994, s. 21). Değerler, gençlikte özellikle "kimlik arayışı" ile ilişkili olabilmeleri açısından önemlidir. Zihinsel kapasitede önemli bir değişim ve gelişimin olduğu gençlik döneminde, dinî ve felsefî sorgulamalar ve bunların sonuçları ile genç bir dünya görüşüne ulaşmanın yanı sıra bir değerler sistemine de 
gereksinim hisseder (Mehmedoğlu, 2016, s. 142). Bu noktada dinin önemli rol oynayabildiğini söylemek mümkündür.

Schwartz ve Bilsky'nin birlikte yaptığı çalışmada inceledikleri değer tanımlarında beş tane ortak yön tespit etmişlerdir. Schwartz ve Smith (1997) ise bu özellikleri daha geniş bir biçimde ele almışlardır. Bu özellikler şunlardır:

1. Değerler inançlardır. Ama nesnel ve soğuk fikir demetleri değillerdir. Bilakis, değerler kişilerde faal hale geldikleri zaman duygular üzerinde etkili olmaktadırlar.

2. Değerler arzu edilen gayelere (eşitlik gibi) ve bu gayelere ulaşmaya katkıda bulunan davranış tarzlarına yönlendirirler.

3. Değerler belirli faaliyet ve durumları aşan olgulardır. Örneğin, boyun eğme, iş veya okulla, spor veya ticaretle, aileyle, arkadaşlar veya yabancılarla alakalı olabilir.

4. Değerler davranışların, insanların ve olayların tercih edilmesi veya değerlendirilmesinde kılavuzluk eden standartlar olarak fayda sağlayabilirler.

5. Değerler birbiri arasında önem derecelerine göre tanzim edilirler. Tanzim edilmiş olan değer kümelerinden bir değer öncelikleri sistemi teşekkül eder. Kültürler ve fertler değer öncelikleri sistemleri ile karakterize edilirler.(Schwartz \& Bilsky, 1987, s. 551; Smith \& Schwartz, 1997, s. 80)

Schwartz, 20 ülke vatandaşları üzerinde yaptığı çalışmada bireysel değerleri toplamda 11 temel unsur olarak ele almaktadır:

1. Öz-yönelim (Self-Direction): Bu değer türünü tanımlayan amaçlar bağımsız düşünce ve eylem seçimi, yaratıcılık ve keşfetmedir. Öz-yönelim, kontrol ve ustalık ile özerklik ve bağımsızlığın etkileşimli ihtiyaçları temel alınarak türetilmiştir. Bu türün değer kümesi, "yaratıcılık, özgürlük, kendi hedeflerini seçme, merak ve bağımsızlık" olarak belirlenmiştir. 
2. Uyarılma (Stimulation): Uyarılma değerleri, en üst düzeyde faaliyete geçirilmesi ve söz konusu seviyeyi sürdürebilmesi için, organizmanın öngörülen çeşitlilik ve uyarılma ihtiyacından kaynaklanmaktadır. Bu ihtiyaç muhtemelen öz-yönelim değerlerinin altında yatan intiyaçlarla ilgilidir. Sosyal deneyim tarafından koşullandırı mış, uyarma ve uyarılma intiyacında biyolojik temelli varyasyonlar, uyarım değerlerinin öneminde bireysel farklılıklar üretebilir. Böyle bir biyolojik temel, heyecan arayan, uyarım değerleriyle ilgili bir kişilik değişkeni olarak iddia edilmiştir. Uyarılma değerlerinin motivasyonel amacı, hayattaki heyecan, yenilik ve meydan okumadır (farklı bir hayat, heyecan verici bir hayat, cesaret).

3. Hazcılık (Hedonism): Organizma ihtiyaçlarından ve onları tatmin etmekten duyulan memnuniyetten türeyen bu değer türü, birçok disiplinin akademisyenleri tarafından anılmaktadır. Bu türün motivasyonel amacını, kendilik için zevk veya duyumsal tatmin olarak tanımlayabiliriz.

4. Başarı (Achievement): Bu değer tipinin tanımlayıcı amacı, sosyal standartlara göre yetkinliği göstererek kişisel başarı elde etmedir. Yetkin performans, bireylerin hayatta kalmak için kaynak elde etmesi ve sosyal etkileşim ve kurumsal işleyişin başarılı olması için bir gerekliliktir. Başarı değerleri birçok kaynakta belirtilmiştir. Burada tanımlandığı gibi başarı değerleri, geçerli kültürel standartlar bakımından yeterliliği ortaya koymakta ve böylece sosyal açıdan onay elde edilmesini vurgulamaktadır.

5. Güç (Power): Güç değerleri büyük intimalle birden fazla türde evrensel intiyaca dayanmaktadır. Toplumsal kurumların işleyişi görünüşte bir dereceye kadar statü farklılaşmasını gerektirmektedir. Ayrıca, hem kültürler içinde hem de kültürler arasında kişilerarası ilişkiler deneysel olarak analiz edildiğinde çoğunlukla bir hâkimiyet/boyun eğme boyutu ortaya çıkmaktadır. Toplumsal hayata dair bu gerçeği haklı çıkarmak ve grup üyelerini kabul etmeye motive etmek için gruplar, gücü bir değer olarak ele alma mecburiyetindedirler. Güç değerleri, toplumsal motivasyon analistleri 
tarafından belirlenen hakimiyet ve kontrol için bireysel intiyaçların dönüşümleri de olabilirler.

6. Güvenlik (Security): Bu değer tipinin motivasyonel amacı toplumun, ilişkilerin ve benliğin güvenliği, uyumu ve istikrarıdır. Temel birey ve grup ihtiyaçlarından kaynaklanırlar. Tek bir güvenlik değeri türünden veya birey ve grup olmak üzere iki farklı türden bahsedilebilir. Bu, bazı güvenlik değerlerinin öncelikli olarak bireysel çıkarlara hizmet ettiğini (örneğin sağlık) ve diğerlerinin öncelikli olarak toplumsal çıkarlara (örneğin, ulusal güvenlik) hizmet ettiğini veya toplumsallığa atıfta bulunan değerlerin bile, önemli ölçüde, (bireyin onlarla kendini tanımlamasından ötürü) bireysel güvenlik hedefini ifade eder.

7. Uyma (Conformity): Bu değer tipinin tanımlayıcı amacı, başkalarını üzecek veya başkalarına zarar verecek ve sosyal beklentileri veya normları ihlal edebilecek eylemlerin, eğilimlerin ve dürtülerin kısıtlanmasıdır. Etkileşim ve grup işleyişinin düzgün bir şekilde işleyebilmesi için bireylerin sosyal olarak yıkıcı olabilecek eğilimlerinin engellemesi gerekliliğinden kaynaklanır. Hemen hemen tüm değer analizlerinde uygunluk tipi değerleri belirtilmiştir. Uyum değerleri gündelik etkileşimde, genellikle yakın olanlarla (itaatkârlık, öz disiplin, nezaket, ebeveynleri ve yaşlıları onurlandırmak) kendi kendini kısıtlama şeklinde ortaya çıkmaktadır.

8. Geleneksellik (Tradition): Her yerdeki gruplar paylaşılan tecrübelerini ve yazgılarını temsil eden semboller ve uygulamalar geliştirir. Bunlar sonunda grup üyeleri tarafından değerli olan gelenekler ve örfler olarak onaylanır. Geleneksel davranış biçimleri, grup dayanışmasının, onun benzersiz değerini ortaya koyan ifadelerin ve grubun hayatta kalmanın kefili olduğu varsayımının simgeleridirler. Gelenekler daha ziyade dini ritüeller, inançlar ve davranış kalıpları şeklinde ortaya çıkarlar. Gelenek değerlerinin motivasyonel amacı; bireyin kültürünün veya dinin kişiye vaz ettiği gelenek ve fikirlerin saygı ve bağlılık duyularak kabul edilmeleridir. 
9. Maneviyat (Spirituality/Self-transcendence) ${ }^{\dagger}$ : İlahiyatçılar ve filozoflar geleneksel inanç ve geleneklerin temel mantığının, günlük varoluşun görünmeyen anlamsızlığı karşısında, hayatı anlam ve tutarlılıkla donatmak olduğunu ifade ederler. Dinlerin çoğu, doğaüstü bir varlığa veya kuvvete atıfta bulunarak gerçekliğin nihai anlamının sorusuna cevap verirler; hümanizm gibi din dışı perspektifler de doğal dünyada anlam kaynaklarının yerini tespit eder. Bu cevaplar genel olarak manevi kaygılara atıfta bulunurlar. Burada incelenen potansiyel maneviyat değerleri, çok çeşitli kaynaklardan toplanmıştır. Değerler, manevi bir hayatı, hayatın anlamını, iç uyumu, ayrılığı, doğayla bütünleşmeyi, teslimiyeti ve dindarlığı içerir.

10. İyilikseverlik (Benevolence): Bu değer türü, toplum yanlısı (prosocial) değer tipinin daraltılarak belli bir çerçevede tanımlanmış şeklidir. Toplum yanlısı birey, bütün ortamlarda tüm insanların refahı için kaygı duyarken, iyiliksever, daha ziyade günlük etkileşimde yakınlarının refahına odaklanır. İyilikseverlik değerlerinin motivasyonel amacı, sık sık kişisel iletişim halinde olunan kişilerin (yardımseverlik, sadakat, bağışlayıcılık, dürüstlük, sorumluluk, gerçek arkadaşlık, olgun bir haldeki aşk) refahının korunması ve geliştirilmesidir.

11. Evrenselcilik (Universalism): Bu değer tipi Schwartz tarafından daha eskiden ortaya konan olgunluk ve toplum yanlısı (prosocial) değer tiplerini kısmen bünyesinde barındırmaktadır. Schwartz, evrensel değer türünün yedi farklı ülkede yapılan deneysel araştırmalar neticesinde ortaya çıktığını ifade etmektedir. Önceleri Maslow'un kendini gerçekleştiren kişi kavramını esas alan Schwartz bu kavramla ilgili deneysel olarak evrensel bir motivasyona ulaşamamıştır. Bundan dolayı, kavramsal olarak daha güçlü olan değerlerin bir bölümlendirilmesini yapmış ve sonuç olarak, evrenselcilik şeklinde ifade edilen değer türü ortaya çıkmıştır. Evrenselciliğin motivasyonel

\footnotetext{
† Bu değer türü bağımsız bir faktör olarak tespit edilemediği için Schwartz'ın daha sonraki çalışmalarında kaldırılmıştır (bkz. Ulu, 2018). Ancak Yapıcı, Kutlu ve Bilican (2012) yaptıkları faktör analizinde Türk toplumunda dindarlık/maneviyatın yeniden değer kategorileri içinde olduğunu tespit emiştir (bkz. Yapıcı, Kutlu, \& Bilican, 2014).
} 
amacı, tüm insanların ve doğanın refahı için anlayış, takdir, hoşgörü ve korumadır (Schwartz, 1992, ss. 5-12).

\section{Hayatın Anlamı ve Değer Yönelimleri Arasındaki İlişki}

Hayatın anlamı ile değerler arasında güçlü bir bağlantı mevcuttur. İki olgu arasındaki bağlantıda dinin mühim bir etken olduğu görülmektedir. Zira din insanın hem anlam hem de değerler konusundaki arayışlarına cevap üreten bir yapıya sahiptir. İnsanın hayatının anlam ve amacının ne olduğu sorusunda cevap veren din bu konuda amaca ulaşmada insanın riayet etmesi gereken değerleri de ortaya koymaktadır. Din değerler ve hayatın niteliğine dair sunduğu izahlar ile insan hayatına anlam sunar (Özdoğan, 2005, s. 59). Din açısından, hayatın anlam ve amacına ulaşmanın hakiki bir surette olabilmesi için değerler de işin içinde olmalı ve onlara hayatın içinde din tarafından tayin edilen konumları verilmelidir. Dolayısıyla, yalnızca değerlere uygun bir şekilde yaşanılan hayat amaçlı ve anlamlı bir hayat olacaktır. Nitekim Bahadır'a göre değerler insanı aşan bir kaynaktan neşv-ü nema bulurlar. Birey hakiki hürriyetine yalnızca kendisinden daha öteye varmasına yardım edecek ulvî değerlere sarılması yoluyla ulaşabilir. Böylelikle insanın iç âleminde bir derinliğe ve güzelliğe ulaşması mümkün olur. Aşkın yönleri itibariyle ulvî bir konumu bulunan değerler anlamlılığa da katkı sağlarlar, bu yönüyle anlamın da insanı aşan bir olgu olduğu söylenebilir (Bahadır, 2011, s. 39). Yine değerlerin insan hayatında önem kazanmasında onlara atfedilen anlamlar büyük rol oynamaktadır. Bu doğrultuda denilebilir ki anlam ile değerler arasında karşılıklı bir ilişki söz konusudur. Anlam terapisi olarak ifade edilebilecek olan logoterapinin kurucusu Frankl'a göre ise insanın anlam istemi yalnızca değerleri benimseyip onları tatbik etmekle yerine getirilebilir. Anlam ve değerler arasındaki bağlantıda değerler, bir tür anlamı mümkün kılan olgular olarak ortaya çıkarlar. Değerlerin evrensel oldukları kanaatinde olan Frankl'a göre değerler üzerinde görülen birtakım farklılaşmalar, esasında öze taalluk etmeyip kişilerin değerlere yönelik bakış açılarından kaynaklanmaktadır. Frankl, değerlerin yüceltme, savunma mekanizması vb. 
ile açıklanmasına katılmaz. Zira değerlerin asıl kaynakları tanrıdır. Değer ve anlam arasındaki güçlü ilişkiye dair yapılan bir araştırmaya göre ise iki olgu arasında güçlü bir korelasyon vardır. 213 kişi üzerinde yürütülen söz konusu çalışmaya göre bireyler değerli olarak gördükleri hususları anlamlı, anlamlı olarak gördükleri hususları ise değerli olarak ifade etmişlerdir (Akt. Bahadır, 2000 , s. 193). Bu noktada hayatın anlamı ile değerini eşdeğer gören yaklaşımlar da mevcuttur. Hayata anlam vermede insanın temel birtakım kaidelere intiyaç hissettiği söylenebilir. Bu noktada değerler ve inançlar yol gösterici bir rol üstlenebilirler. Zira insanın hayatında değerler ve inançlar, birer referans noktası olarak işlev görerek insanın olayları değerlendirişi, anlamlandırışı, tavır alışı, hareket tarzı gibi insan hayatının hemen her noktasına tesir etmektedirler (Akıncı, 2005, ss. 10-11).

\section{Yöntem}

Araştırmanın amacı çerçevesinde aşağıdaki alt sorulara cevap aranmıştır.

a. Lise öğrencilerinin sahip olduğu değerler cinsiyete göre anlamlı düzeyde farklılaşmakta mıdır?

b. Lise öğrencilerinde hayatın anlamı cinsiyete göre anlamlı düzeyde farklılaşmakta mıdır?

c. Lise öğrencilerinin sahip oldukları değerler ile hayatlarının anlamı arasında anlamlı bir ilişki var mıdır?

d. Lise öğrencilerinin sahip olmuş olduğu değerler hayatlarının anlamını anlamlı düzeyde yordamakta mıdır?

\section{Katılımcılar}

Bu çalışmada Kayseri ilindeki 3 farklı devlet lisesinde öğrenim gören 507 öğrenciden veri toplanmıştır. Katılımcı grubu tesadüfi olmayan örnekleme yöntemlerinden "uygun/kolayda örnekleme" yöntemi yardımıyla seçilmiştir. 
Katılımcıların \%30'unu ( $n=150)$ erkek öğrenciler, \%70'ini ise $(n=357)$ kız öğrenciler oluşturmaktadır.

\section{Veri Toplama Araçları}

a. Hayatın Amacı Ölçeği: Hayat kalitesi, anlam-amaç ve özgürlük olmak üzere üç faktörden ve 16 maddeden oluşan ölçek Crumbaugh ve Maholick tarafından geliştirilmiş ve Türkçeye Ferdi Kıraç tarafından uyarlanarak geçerlilik ve güvenilirlik çalışmaları yapılmıştır (Kıraç, 2015). Ölçeğin Cronbach Alfa iç tutarlılık katsayısı 0.90 ve iki yarım güvenirlik katsayısı 0,85 olarak tespit edilmiştir. Bu çalışmada ise Cronbach Alfa iç tutarlılık katsayısı 0,87 olarak bulgulanmıştır.

b. Portre Değerler Anketi: Söz konusu ölçek Schwartz, Melech, Lehmann, Burges, Harris ve Owens tarafından geliştirilmiştir (Schwartz vd., 2001). Demirutku ve Sümer ise ölçeği Türkçeye uyarlamışlardır (Demirutku \& Sümer, 2010). Ölçekte 40 madde bulunmakta olup değerlendirme 6'lı Likert tipi bir derecelendirme üzerinden yapılmıştır. Buna göre "1: bana çok benziyor, 2: bana benziyor, 3: bana az benziyor, 4: bana çok az benziyor, 5: bana benzemiyor ve 6: bana hiç benzemiyor" şeklindedir. Ölçekte güç, başarı, hazcılık, uyarılım, öz-yönelim, evrenselcilik, iyilikseverlik, geleneksellik, uyma ve güvenlik şeklinde adlandırılan 10 faktör bulunmaktadır. Demirutku ve Sümer'in çalışmalarında Cronbach Alfa iç tutarlılık katsayısı 0.61 ile 0.84 arasında; test-tekrar test güvenirlik katsayısı ise 0.65 ile 0.82 arasında değişmektedir. Bu çalışmada ise Cronbach Alfa iç tutarlılık katsayısı 0,88 olarak bulgulanmıştır.

\section{Verilerin Analizi}

Veriler nicel analiz tekniklerine göre analiz edilmiştir. Betimsel istatistik tekniklerinden ortalama ve standart sapma değerleri; çıkarımsal istatistik tekniklerinden iki ortalama arasındaki farkı tespit etmek amacıyla bağımsız gruplar t-testi; değişkenler arasındaki ilişkileri belirlemek amacıyla ise Pearson Momentler Çarpımı Korelasyon tekniği ve Regresyon analizi kullanılmıştır. 


\section{4. İşlem}

Öncelikle öğrencilere çalışma hakkında bilgi verilmiş ve araştırmaya gönüllü olarak katılmak isteyen öğrencilere uygulanmıştır. Verilerin sadece bilimsel araştırma kapsamında ve anonim olarak kullanılacağı konusunda katılımcılara bilgi verilmiştir.

\section{E. Bulgular}

$\mathrm{Bu}$ çalışmanın bulguları, betimsel ve çıkarımsal istatistik analizi sonuçları bağlamında başlıklar şeklinde sırayla verilmiştir.

\section{Betimsel İstatistik Analizi Bulguları}

Çalışmanın değişkenlerine ait minimum ve maksimum değerler, ortalama ve standart sapma değerleri Tablo 1'de verilmektedir.

Tablo 1: Çalışmanın Değişkenlerine İlişkin Betimsel İstatistik Değerleri

\begin{tabular}{|l|l|l|l|l|l|}
\hline Değişkenler & N & Min. & Max. & Ort. & $\begin{array}{l}\text { Standart } \\
\text { Sapma }\end{array}$ \\
\hline Güç & 507 & 1 & 6 & 3,90 & 1,25 \\
\hline Başarı & 507 & 1 & 6 & 4,49 & 1,13 \\
\hline Hazcılık & 507 & 1 & 6 & 4,72 & 1,14 \\
\hline Uyarılma & 507 & 1 & 6 & 4,68 &, 98 \\
\hline Öz-yönlendirme & 507 & 1 & 6 & 4,94 &, 88 \\
\hline Evrenselcilik & 507 & 2 & 6 & 4,92 &, 88 \\
\hline
\end{tabular}


1216 | Arş. Gör. Abdullah TANRIVERDi, Dr. Öğr. Üyesi Mustafa ULU

\begin{tabular}{|l|l|l|l|l|l|}
\hline İilikseverlik & 507 & 1 & 6 & 4,71 &, 99 \\
\hline Geleneksellik & 507 & 1 & 6 & 4,24 & 1,0 \\
\hline Uyma & 507 & 1 & 6 & 4,46 & 1,02 \\
\hline Güvenlik Yönelimi & 507 & 1,55 & 5,75 & 4,63 &, 61 \\
\hline $\begin{array}{l}\text { Değer } \\
\text { Ölçeği }\end{array}$ & 507 & 1 & 6 & 4,85 &, 83 \\
\hline Hayat Kalitesi & 507 & 1 & 5 & 2,91 &, 86 \\
\hline Anlam ve Amaç & 507 & 1 & 5 & 3,89 &, 82 \\
\hline Özgürlük Amacı & 507 & 1 & 5 & 3,40 &, 74 \\
\hline $\begin{array}{l}\text { Hayatın } \\
\text { Ölçeği }\end{array}$ & 507 & 1 & 5 & 3,38 & 1,17 \\
\hline
\end{tabular}

Tabloda da görüleceği gibi katılımcılar değer yönelimlerinde en yüksek ortalamaya öz-yönlendirme (Ort. $=4,94 ; S=0,88$ ) ve en düşük ortalamaya ise güç (Ort.=3,90; $S=1,25)$ değer yöneliminde sahiptir. Değer yönelimi ölçeğinin toplam puanı açısından ortalaması 4,63; standart sapması ise 0,61'dir.

Yine katılımcılar Hayatın Amacı ölçeğinde en yüksek ortalamaya Anlam ve Amaç faktöründe (Ort.=3,89; $\mathrm{S}=0,82$ ), en düşük ortalamaya ise Hayat Kalitesi faktöründe (Ort. $=2,91 ; S=0,86$ ) sahip olmuşlardır. Hayatın Amacı Ölçeğinin toplam puanı açısından ortalaması 3,40 ve standart sapması 0,74 'dür. 


\section{2. Çıkarımsal İstatistik Analizi Bulguları}

Katılımcıların cinsiyetlerine göre çalışmanın değişkenleri arasında anlamlı bir farklılık olup olmadığını incelemek amacıyla Bağımsız Gruplar tTesti yapılmış ve analiz sonuçları Tablo 2'de verilmiştir.

\section{a. Bağımsız Örneklem t-Testi Sonuçları}

Tablo 2: Cinsiyet Değişkenine Göre Bağımsız Gruplar t-testi

\begin{tabular}{|c|c|c|c|c|c|c|}
\hline Değişkenler & Cinsiyet & $\mathbf{N}$ & Ort. & $\begin{array}{l}\text { Standart } \\
\text { Sapma }\end{array}$ & $\mathbf{t}$ & $p$ \\
\hline \multirow[b]{2}{*}{ Güç } & Kadın & 357 & 3,81 & 1,23 & \multirow[b]{2}{*}{$-2,42$} & \multirow[b]{2}{*}{,016 } \\
\hline & Erkek & 150 & 4,10 & 1,26 & & \\
\hline \multirow[b]{2}{*}{ Başarı } & Kadın & 357 & 4,46 & 1,16 & \multirow[b]{2}{*}{,- 93} & \multirow[b]{2}{*}{,352 } \\
\hline & Erkek & 150 & 4,56 & 1,06 & & \\
\hline \multirow[b]{2}{*}{ Hazcılık } & Kadın & 357 & 4,72 & 1,17 & \multirow[b]{2}{*}{,- 16} & \multirow[b]{2}{*}{870} \\
\hline & Erkek & 150 & 4,73 & 1,08 & & \\
\hline \multirow[b]{2}{*}{ Uyarılma } & Kadın & 357 & 4,70 & ,97 & \multirow[b]{2}{*}{,93 } & \multirow[b]{2}{*}{,354 } \\
\hline & Erkek & 150 & 4,62 & 1,00 & & \\
\hline \multirow[b]{2}{*}{$\begin{array}{l}\text { Öz- } \\
\text { yönlendirme }\end{array}$} & Kadın & 357 & 4,91 & ,88 & \multirow[b]{2}{*}{$-1,22$} & \multirow[b]{2}{*}{,224 } \\
\hline & Erkek & 150 & 5,01 & ,88 & & \\
\hline \multirow{3}{*}{ Evrenselcilik } & Kadın & 357 & 5,01 & ,84 & \multirow[b]{2}{*}{3,72} & \multirow[b]{2}{*}{,000 } \\
\hline & Erkek & 150 & 4,70 & ,94 & & \\
\hline & Kadın & 357 & 4,81 & 1,00 & & \\
\hline
\end{tabular}


1218 | Arş. Gör. Abdullah TANRIVERDi, Dr. Öğr. Üyesi Mustafa ULU

\begin{tabular}{|c|c|c|c|c|c|c|}
\hline İyilikseverlik & Erkek & 150 & 4,50 & ,95 & 3,23 & ,001 \\
\hline \multirow[b]{2}{*}{ Geleneksellik } & Kadın & 357 & 4,29 & ,99 & \multirow[b]{2}{*}{1,834} & \multirow[b]{2}{*}{,067 } \\
\hline & Erkek & 150 & 4,11 & 1,02 & & \\
\hline \multirow[b]{2}{*}{ Uyma } & Kadın & 357 & 4,49 & 1,05 & \multirow[b]{2}{*}{ 83 } & \multirow[b]{2}{*}{,403 } \\
\hline & Erkek & 150 & 4,40 & 96 & & \\
\hline \multirow[t]{2}{*}{ Güvenlik } & Kadın & 357 & 4,88 & ,82 & \multirow[b]{2}{*}{1,52} & \multirow[b]{2}{*}{ 130 } \\
\hline & Erkek & 150 & 4,76 & ,86 & & \\
\hline \multirow[b]{2}{*}{$\begin{array}{l}\text { Değer } \\
\text { Yönelimi } \\
\text { Ölçeği }\end{array}$} & Kadın & 357 & 4,65 & 62 & \multirow[b]{2}{*}{1,40} & \multirow[b]{2}{*}{, 165 } \\
\hline & Erkek & 150 & 4,57 & ,60 & & \\
\hline \multirow[b]{2}{*}{ Hayat Kalitesi } & Kadın & 357 & 2,88 & 87 & \multirow[b]{2}{*}{$-1,29$} & \multirow[b]{2}{*}{ 200 } \\
\hline & Erkek & 150 & 2,99 & ,85 & & \\
\hline \multirow[b]{2}{*}{$\begin{array}{l}\text { Anlam ve } \\
\text { Amaç }\end{array}$} & Kadın & 357 & 3,86 & 83 & \multirow[b]{2}{*}{$-1,29$} & \multirow[b]{2}{*}{ 197 } \\
\hline & Erkek & 150 & 3,96 & ,81 & & \\
\hline \multirow[b]{2}{*}{ Özgürlük } & Kadın & 357 & 3,34 & 1,19 & \multirow[b]{2}{*}{,- 96} & \multirow[b]{2}{*}{ 339 } \\
\hline & Erkek & 150 & 3,45 & 1,12 & & \\
\hline \multirow[b]{2}{*}{$\begin{array}{l}\text { Hayatın Amacı } \\
\text { Ölçeği }\end{array}$} & Kadın & 357 & 3,37 & ,76 & \multirow[b]{2}{*}{$-1,48$} & \multirow[b]{2}{*}{,140 } \\
\hline & Erkek & 150 & 3,47 & ,70 & & \\
\hline
\end{tabular}


Tablo 2'deki verilere göre, değer yönelimlerinde iyilikseverlik ve evrenselcilikte kadınların; güçte ise erkeklerin ortalama puanları anlamlı olarak daha yüksektir.

Kadınların ortalama puanları iyilikseverlikte (Ort. $=4,81 ; \quad S=1,00$ ) erkeklerin ortalama puanlarından (Ort. $=4,50 ; S=0,95)$ anlamlı olarak daha yüksektir $(\mathrm{t}=3,23 ; \mathrm{p}=, 001)$. Evrenselcilikte kadınların ortalama puanları (Ort. $=5,01 ; S=0,84)$ erkeklerin ortalama puanlarından (Ort. $=4,70 ; S=0,94$ ) anlamlı olarak daha yüksektir $(t=3,72 ; p=, 000)$. Güçte erkeklerin ortalama puanları (Ort. $=4,10 ; S=1,26)$ kadınların ortalama puanlarından (Ort. $=3,81$; $S=1,023)$ anlamlı olarak daha yüksektir $(t=-2,42 ; p=, 016)$.

Katılımcıların Hayatın Amacı ölçeğinden elde ettikleri puanlar arasında faktör bazlı yapılan analizde cinsiyet açısından istatistiksel olarak farklılaşmadıkları görülmektedir.

\section{b. Korelasyon Analizi Sonuçları}

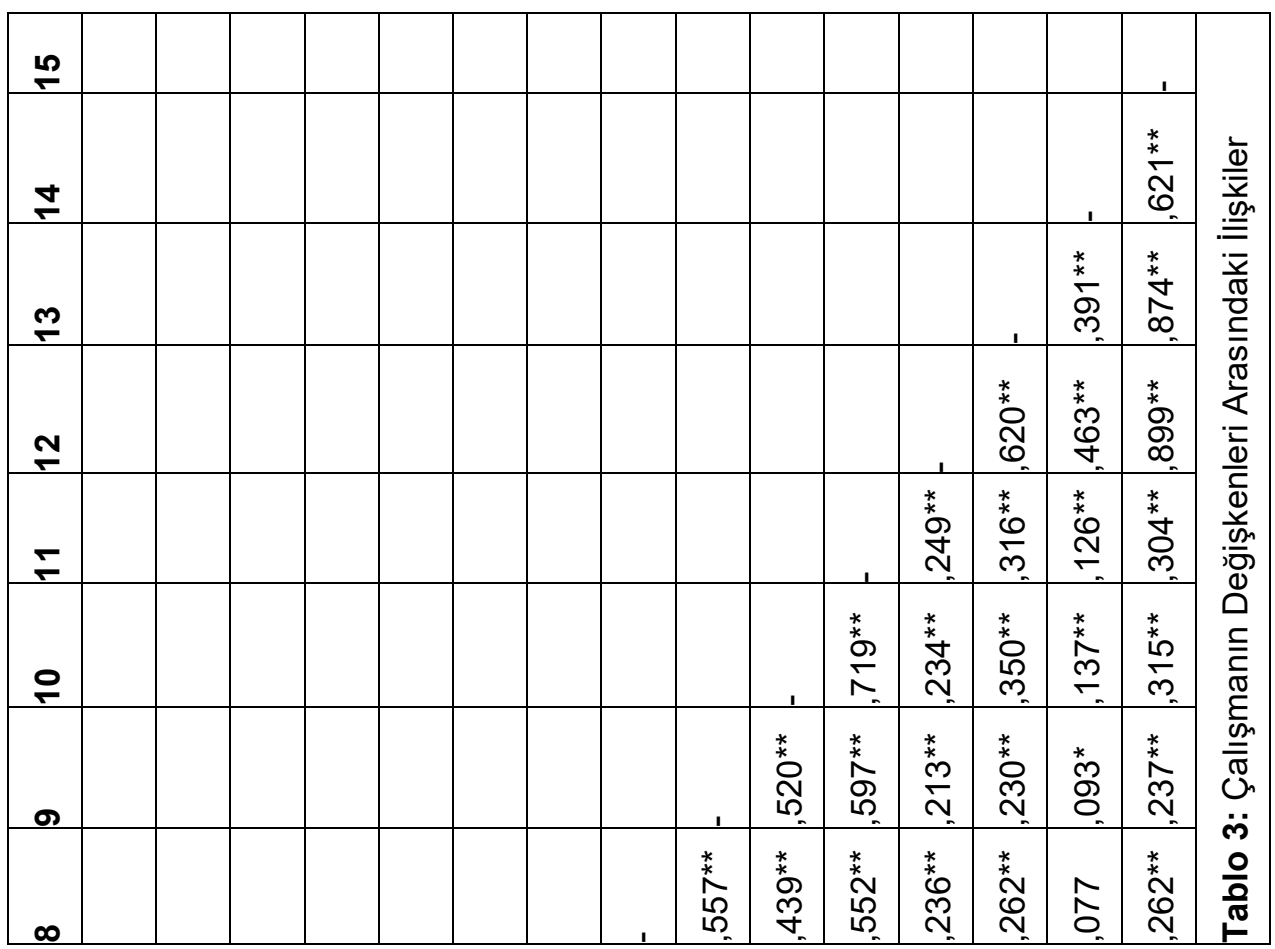




\begin{tabular}{|c|c|c|c|c|c|c|c|c|c|c|c|c|c|c|c|}
\hline$\Lambda$ & & & & & & & 1 & 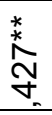 & 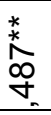 & $\begin{array}{l}\stackrel{*}{*} \\
\stackrel{m}{\sim} \\
\underset{+}{+}\end{array}$ & \begin{tabular}{l}
$*$ \\
\multirow{2}{*}{} \\
$\check{\infty}$ \\
0 \\
0
\end{tabular} & 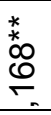 & 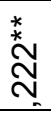 & లె & \begin{tabular}{l}
$*$ \\
\multirow{2}{*}{} \\
g \\
$\stackrel{2}{\circ}$
\end{tabular} \\
\hline 0 & & & & & & & 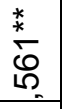 & $\stackrel{*}{\leftarrow} \underset{\wp}{+}$ & 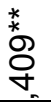 & 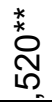 & \begin{tabular}{l}
$*$ \\
\multirow{*}{*}{} \\
$\stackrel{N}{N}$ \\
$\stackrel{2}{N}$
\end{tabular} & $\stackrel{*^{*}}{\stackrel{*}{N}}$ & $\stackrel{*}{\stackrel{*}{ \pm}}$ & $\stackrel{N}{N}$ & 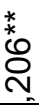 \\
\hline م & & & & & & $\begin{array}{l}\stackrel{*}{*}{ }^{6} \\
\stackrel{m}{+}\end{array}$ & 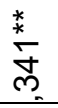 & 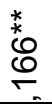 & 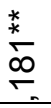 & 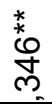 & $\frac{*^{*}}{\overbrace{0}^{\prime}}$ & $\begin{array}{l}\stackrel{*}{*} \\
\stackrel{m}{m} \\
\leftarrow\end{array}$ & $\begin{array}{l}\stackrel{*}{*} \stackrel{2}{\circ} \\
\stackrel{2}{\leftarrow}\end{array}$ & 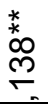 & 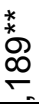 \\
\hline$\checkmark$ & & & & & \begin{tabular}{l} 
* \\
\multirow{2}{0}{} \\
0 \\
0
\end{tabular} & $\begin{array}{l}{ }^{*} \\
\stackrel{*}{*} \\
n_{n}\end{array}$ & $\stackrel{*}{\stackrel{*}{N}} \underset{N}{N}$ & 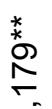 & 寺 & 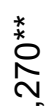 & $\begin{array}{l}\stackrel{*}{*} \\
\stackrel{2}{N} \\
\stackrel{n}{0}\end{array}$ & 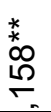 & $\stackrel{*}{*} \stackrel{0}{\circ}$ & 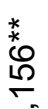 & 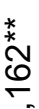 \\
\hline$m$ & & & & 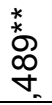 & 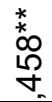 & 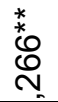 & 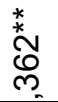 & ஜ్రి & $\stackrel{*}{\circ}$ & $\stackrel{*^{*}}{\stackrel{+}{+}}$ & $\begin{array}{l}\text { * } \\
\stackrel{*}{*} \\
\infty \\
0 \\
0\end{array}$ & 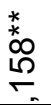 & $\stackrel{*}{\stackrel{*}{*}}$ & న & 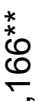 \\
\hline$\sim$ & & & 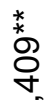 & 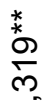 & 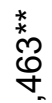 & 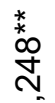 & $\stackrel{*}{\stackrel{*}{*}} \stackrel{\text { ㄱ. }}{\stackrel{2}{n}}$ & চ) & 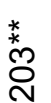 & $\begin{array}{l}\stackrel{*}{*}{ }^{\circ} \\
\text { ᄋ } \\
\text { m. }\end{array}$ & 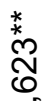 & 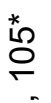 & $\begin{array}{l}\text { * } \\
\text { ه } \\
\wp\end{array}$ & $\stackrel{0}{8}$ & $\stackrel{*}{*} \underset{*}{*}$ \\
\hline & 1 & $\begin{array}{l}* \\
\text { * } \\
\text { O } \\
\text { ্ }\end{array}$ & $\begin{array}{l}\text { * } \\
\text { ก } \\
\stackrel{2}{+}\end{array}$ & 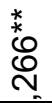 & $\stackrel{*^{*}}{\stackrel{*}{+}}$ & 요 & \& & $\stackrel{*}{*} \stackrel{\circ}{\circ}$ & $\begin{array}{l}\infty \\
8 \\
8\end{array}$ & 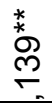 & $\begin{array}{l}\stackrel{*}{*} \\
\stackrel{\text { }}{\text { m }}\end{array}$ & $\begin{array}{l}\text { o } \\
0 \\
0\end{array}$ & 용 & 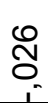 & ஜ̊ \\
\hline 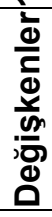 & $\begin{array}{l}\text { بn } \\
\text { : }\end{array}$ & 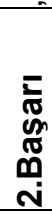 & $\begin{array}{l}\text { x } \\
\bar{N} \\
\text { N } \\
\text { I } \\
\text { m. }\end{array}$ & 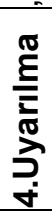 & مْ & 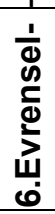 & 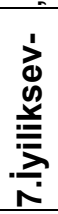 & 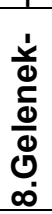 & $\underset{\sigma}{\stackrel{\mathbb{\sigma}}{\xi}}$ & $\begin{array}{l}\text { 兰 } \\
\text { c } \\
0 \\
: 3 \\
0 \\
0 \\
0\end{array}$ & 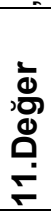 & 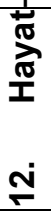 & 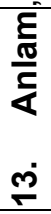 & $\stackrel{+}{\dot{I}}$ & 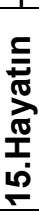 \\
\hline
\end{tabular}

Tabloda görüldüğü gibi güç ile başarı $(r=, 499 ; p=, 000)$, hazcılık $(r=, 403$; $p=, 000)$, uyarılma $(r=, 266 ; p=, 000)$, öz-yönlendirme $(r=, 344 ; p=, 000)$ ve güvenlik $(r=, 139 ; p=, 002)$ arasında pozitif; geleneksellik $(r=-, 100 ; p=, 025)$ arasında ise negatif bir ilişki olduğu görülmektedir. Başarı ile hazcılık ( $r=, 409$; $\mathrm{p}=, 000)$, uyarılma $(r=, 319 ; \mathrm{p}=, 000)$, öz-yönlendirme $(r=, 463 ; \mathrm{p}=, 000)$, evrenselcilik $(r=, 248 ; p=, 000)$, iyilikseverlik $(r=, 210 ; p=, 000)$, uyma $(r=, 203$; $p=, 000)$, güvenlik $(r=, 390 ; p=, 000)$, hayat kalitesi $(r=, 105 ; p=, 018)$, anlam ve amaç $(r=, 169 ; p=, 000)$ arasında pozitif ilişki olduğu bulgulanmıştır. Hazcılık ile uyarılma $(r=, 489 ; p=, 000)$, öz-yönlendirme $(r=, 458 ; p=, 000)$, evrenselcilik $(r=, 266 ; \mathrm{p}=, 000)$, iyilikseverlik $(r=, 362 ; \mathrm{p}=, 000)$, uyma $(r=, 101 ; \mathrm{p}=, 023)$, güvenlik $(r=, 244 ; p=, 000)$, hayat kalitesi $(r=, 499 ; p=, 000)$, anlam ve amaç $(r=, 147 ; p=, 001)$ arasında pozitif ilişki olduğu görülmektedir. Uyarılma ile özyönlendirme $(r=, 506 ; p=, 000)$, evrenselcilik $(r=, 376 ; p=, 000)$, iyilikseverlik $(r=, 277 ; p=, 000)$, geleneksellik $(r=, 179 ; p=, 000)$, güvenlik $(r=, 270 ; p=, 000)$, 
hayat kalitesi $(r=, 158 ; p=, 000)$, anlam ve amaç $(r=, 105 ; p=, 018)$, özgürlük $(r=, 156 ; p=, 000)$ arasında pozitif ilişki olduğu belirlenmiştir. Öz-yönlendirme ile evrenselcilik $(r=, 436 ; p=, 000)$, iyilikseverlik $(r=, 341 ; p=, 000)$, geleneksellik $(r=, 166 ; p=, 000)$, uyma $(r=, 181 ; p=, 000)$, güvenlik $(r=, 346 ; p=, 000)$, hayat kalitesi $(r=, 133 ; p=, 003)$, anlam ve amaç $(r=, 195 ; p=, 000)$ ve özgürlük $(r=, 138$; $\mathrm{p}=, 002)$ arasında pozitif ilişki olduğu bulgulanmıştır. Evrenselcilik ile iyilikseverlik $(r=, 561 ; p=, 000)$, geleneksellik $(r=, 461 ; p=, 000)$, uyma $(r=, 409$; $p=, 000)$, güvenlik $(r=, 520 ; p=, 000)$, hayat kalitesi $(r=, 174 ; p=, 000)$, anlam ve amaç $(r=, 214 ; \quad p=, 000)$ arasında pozitif ilişki olduğu görülmektedir. lyilikseverlik ile geleneksellik ( $r=, 427 ; p=, 000)$, uyma $(r=, 487 ; p=, 000)$, güvenlik $(r=, 432 ; p=, 000)$, hayat kalitesi $(r=, 168 ; p=, 000)$, anlam ve amaç $(r=, 222 ; p=, 000)$ arasında pozitif ilişki olduğu tespit edilmiştir. Geleneksellik ile uyma $(r=, 557 ; \mathrm{p}=, 000)$, güvenlik $(r=, 439 ; \mathrm{p}=, 000)$, hayat kalitesi $(r=, 236$; $p=, 000)$, anlam ve amaç $(r=, 262 ; p=, 000)$ arasında pozitif ilişki olduğu belirlenmiştir. Uyma ile güvenlik $(r=, 520 ; p=, 000)$, hayat kalitesi $(r=, 213$; $p=, 000)$, anlam ve amaç $(r=, 230 ; p=, 000)$, özgürlük $(r=, 093 ; p=, 036)$ arasında pozitif ilişki olduğu görülmektedir. Güvenlik ile hayat kalitesi $(r=, 234 ; p=, 000)$, anlam ve amaç $(r=, 350 ; p=, 000)$ ve özgürlük $(r=, 137 ; p=, 002)$ arasında pozitif ilişki olduğu tespit edilmiştir.

Hayat kalitesi ile anlam ve amaç $(r=, 620 ; p=, 000)$ ve özgürlük $(r=, 463$; $\mathrm{p}=, 000)$ arasında pozitif ilişki olduğu tespit edilmiştir. Anlam ve amaç ile özgürlük $(r=, 391 ; p=, 000)$ arasında ise yine pozitif bir ilişki olduğu sonucuna ulaşılmıştır.

Değer Yönelimi Ölçeğinin toplam puanı açısından bakıldığında ölçeğin, hayat kalitesi $(r=, 249 ; p=, 000)$, anlam ve amaç $(r=, 316 ; p=, 000)$ ve özgürlük $(r=, 126 ; p=, 005)$ değişkenleri ile arasında pozitif ilişki olduğu görülmektedir. Dolayısıyla, hayat kalitesi, anlam ve amaç ile özgürlük faktörlerinden alınan puan yükseldikçe Değer Yönelimi Ölçeğinde ulaşılan skor da yükselmektedir.

Ayrıca Hayatın Amacı Ölçeğinin toplam puanı açısından bakıldığında ise ölçeğin, başarı $(r=, 144 ; p=, 001)$, hazcılık $(r=, 166 ; p=, 000)$, uyarılma 
$(r=, 162 ; p=, 000)$, öz-yönlendirme $(r=, 189 ; p=, 000)$, evrenselcilik $(r=, 206$; $\mathrm{p}=, 000)$, iyilikseverlik $(r=, 199 ; \mathrm{p}=, 000)$, geleneksellik $(r=, 262 ; p=, 000)$, uyma $(r=, 237 ; p=, 000)$, güvenlik $(r=, 315 ; p=, 000)$ faktörleri arasında pozitif ilişki olduğu bulgulanmıştır. Bu verilerden hareketle denilebilir ki başarı, hazcılık, uyarılma, öz-yönlendirme, evrenselcilik, iyilikseverlik, geleneksellik, uyma ve güvenlik faktörlerinden alınan puan yükseldikçe Hayatın Amacı Ölçeğinden alınan puan da yükselmektedir.

\section{c. Regresyon Analizi Sonuçları}

Değer yönelimlerinin hayatın amacını yordama gücünü tespit etmek amacıyla regresyon analizi yapılmış ve analiz sonuçları Tablo 4'te verilmiştir.

Tablo 4: Değer Yönelimlerinin Hayatın Amacını Yordaması

\begin{tabular}{|c|c|c|c|c|}
\hline Değişkenler & Beta & $\mathbf{t}$ & $\mathbf{p}$ & $r^{2}$ \\
\hline Güç &,- 15 & $-2,88$ & ,004 & \multirow{10}{*}{0,13} \\
\hline Başarı & ,04 & ,70 & ,486 & \\
\hline Hazcılık & 11 & 2,09 & ,037 & \\
\hline Uyarılma & ,04 & ,71 & ,480 & \\
\hline $\begin{array}{l}\text { Öz- } \\
\text { yönlendirme }\end{array}$ & ,08 & 1,49 & ,138 & \\
\hline Evrenselcilik &,- 07 & $-1,15$ & ,251 & \\
\hline İyilikseverlik &,- 02 &,- 29 & ,772 & \\
\hline Geleneksellik & ,13 & 2,47 & ,014 & \\
\hline Uyma & ,05 & ,88 & ,381 & \\
\hline Güvenlik & ,21 & 3,80 & ,000 & \\
\hline
\end{tabular}

Tablo 4'te görüldüğü gibi değer yönelimlerinden güç $(\beta=-, 15 ; p=, 004)$, hazcılık $(\beta=, 11 ; p=, 037)$ ve geleneksellik $(\beta=, 13 ; p=, 014)$ ve güvenlik $(\beta=, 21$; 
$p=, 000$ ) hayatın amacındaki varyansın \%13'ünü açıklamaktadır. Buna göre hayatın amacını hazcılık, geleneksellik ve güvenlik değer yönelimleri pozitif; güç değer yönelimi ise negatif olarak etkilemektedir. Diğer bir deyişle, hazcılık, geleneksellik ve güvenlik puanlarındaki artış, hayatın anlam ve amacını bulmaya olumlu manada katkı sağlarken; güç puanındaki artış hayatın anlam ve amacını olumsuz manada etkilemektedir. Bu değer yönelimlerinden hayatın amacı üzerinde en fazla olumlu etkiye sahip olan faktör güvenliktir, daha sonra sırasıyla geleneksellik ve hazcılık faktörleri gelmektedir.

\section{Tartışma ve Sonuç}

Bu çalışmada Kayseri'deki üç farklı devlet lisesinde öğrenim gören öğrencilerde hayatta bir anlam ve amaç bulma ile değer yönelimleri arasındaki ilişki ele alınmaya çalışılmıştır. Ayrıca, çalışmada kullanılan değişkenlerin cinsiyete göre farklılaşıp farklılaşmadığının da ortaya konulması hedeflenmiştir.

Araştırmada hayatın anlamı konusunda teorik anlamda temel hareket noktası Freud'un haz istemi ve Adler'in güç isteminin aksine olarak insanın en temel güdüleyicisinin anlam istemi olduğunu söyleyen ve bu durumun engellenmesinin psikolojik sorunlara yol açtığını bildiren Frankl'ın görüşleri temel alınmıştır. Değerler konusunda ise Schwartz'ın değerler yaklaşımından hareket edilmiştir. Literatürde hayatın anlamı ve değerler arasındaki ilişkiyi doğrudan konu edinen yalnızca bir çalışmaya ulaşılabilmiş, ancak çalışmanın örneklem ve kullanılan ölçekler bakımından bu çalışmadan farklılık arz etmesi bakımından bu çalışma ile karşılaştırı ması yapılamamıştır (Baş, 2014; Baş \& Hamarta, 2015).

Değer yönelimi ölçeğinde öğrencilerin en yüksek ortalamayı 4,94 ile özyönelim değerinde almaları oldukça manidardır. Katılımcıların lise öğrencisi oldukları dikkate alındığında bağımsız bir kimlik inşası ve arayışı içerisinde olduklarından dolayı çevresel etkilerden ziyade kendi şahsî görüşlerini oluşturma ve bu çerçevede özgürce hareket etmeye oldukça büyük önem 
atfettikleri görülmektedir. Yine bu ölçekte en düşük ortalamanın olduğu değer ise 3,90 ile güçtür. Bu noktada katılımcıların hâkimiyet/boyun eğdirme, toplumsal statü ve grup üyelerini kabul etmeye motive etmek gibi konularda ortalamanın çok az üstünde bir konumda yer aldıkları söylenebilir (Schwartz, 1992, ss. 5-12). Bu ölçekle lise öğrencileri üzerinde yapılmış doğrudan bir çalışmaya ulaşılamamış olması mukayese imkânını ortadan kaldırmaktadır. Ancak lise örneklemi dışında bu çalışmayla kısmen uyumlu olan birtakım araştırmalar mevcuttur. Bunlardan Roszkowski, Kinzler ve Kane'in çalışmasında katıımcıların en yüksek ortalamaya iyilikseverlik ve en düşük ortalamaya güç değer yöneliminde sahip olduklarını belirtmişlerdir (Roszkowski, Kinzler, \& Kane, 2014, s. 5). Ülkemizde Ulu tarafından üniversite öğrencileri üzerinde yapılan bir çalışmada ise en yüksek ortalama bu çalışmada ikinci en yüksek ortalamaya sahip alan evrenselcilik değeri, en düşük ortalama ise bu çalışma ile uyumlu olarak güç değeri olarak rapor edilmiştir (Ulu, 2018b, s. 183). Özcan ve Erol'un Karabük Üniversitesi öğrencileri üzerinde yaptıkları araştırmaların katıımcıların en yüksek ortalamayı iyilikseverlikte ve en düşük ortalamayı ise hazcılıkta elde ettikleri görülmüştür (Özcan \& Erol, 2017, s. 926). Yine Mehmedoğlu'nun (2016, s. 149), Arslan ve Tunç'un $(2013$, s. 17$)$ ve Karaca'nın $(2008$, s. 68 ) ilahiyat fakültesi öğrencileri üzerinde yaptıkları araştırmaların her birisinde katıımcıların en yüksek ortalamaya iyilikseverlik değerinde, en düşük ortalamaya ise hazcılık değerinde sahip oldukları sonucuna ulaşmışlardır. Ayrıca, Altun Fen Lisesi ve İmam-Hatip Lisesi öğrencileri üzerinde yaptığı çalışmasında en yüksek ortalamaya yardımseverlik değerinde, en düşük ortalamaya ise uyarılma değerinde sahip oldukları ortaya konmuştur (Altun, 2015, ss. 204-205). Kızılgeçit ve diğerleri ise Illahiyat Fakültesi öğrencileri üzerinde yaptıkları çalışmalarında katııımcıların en yüksek ortalamayı iyilikseverlik ve en düşük ortalamayı ise uyarıım değerinde elde ettikleri görülmüştür (Kızılgeçit, Acuner, \& Toklu, 2015, s. 57). Yine, ülkemizde yapılan bir çalışmada Demirutku ve Sümer katııımcıların öz-yönelimde en yüksek ortalamaya ve geleneksellikte en düşük ortalamaya sahip olduklarını tespit 
etmişlerdir (Demirutku \& Sümer, 2010, s. 22). Kıran tarafından Ondokuz Mayıs Üniversitesi öğrencileri örnekleminde yürütülen çalışmaya göre ise öğrencilerin sahip oldukları en yüksek ortalama evrenselcilik; en düşük ortalama ise uyarılma olmuş, bu çalışmanın aksi bulgulara ulaşılmıştır (Kıran, 2016, s. 1269). Bu verilere göre öğrenim düzeyi ve bulunulan psiko-sosyal evrenin değer yönelimleri üzerinde etkili olduğu söylenebilir.

Hayatın amacı ölçeğinde ise öğrencilerin en yüksek ortalamaya 3,89 puan ile anlam ve amaç faktöründe, en düşük ortalamaya ise 2,91 puan ile hayat kalitesi faktöründe sahip oldukları görülmektedir. Buradan hareketle denilebilir ki öğrenciler hayatlarını anlamlı görmekte ve hayatlarında bir amacın var olduğuna inanmaktadırlar. Bu durum öğrencilerin hayattaki konumlarını anlamlandırma açısından ortalamanın üzerinde bir konumda olduklarını gösterirken hayat kalitelerinin ortalamanın altında çıkması dikkat çekicidir. Yani öğrenciler bir yandan hayat standartlarını düşük, zahmetli, sıkıcı ve monoton görürlerken diğer yandan yine de hayatlarının anlamlı olduğu kanaatini taşımaktadırlar. Bu noktada katılımcıların hayatlarında karşılaştıkları zorluklara rağmen hayatlarını anlamlı bulmaları, Frankl'ın hayatın anlamını bulma konusunda zorluk ve acıların da katkı sağlayıcı olduğu fikriyle uygunluk arz ediyor görünmektedir (Frankl, 2016, ss. 126-130). $\mathrm{Bu}$ ölçekle lise öğrencileri üzerinde yapılmış doğrudan bir çalışmaya ulaşılamamış olması mukayese imkânını ortadan kaldırmaktadır.

Cinsiyet değişkenine göre bağımsız gruplar t-testi sonuçlarına bakıldığında hayatın amacı ölçeğinde cinsiyetler arasında anlamlı bir farklılaşmaya rastlanamamıştır. Değer yönelimi ölçeğinde ise iyilikseverlik ve evrenselcilik değerlerinde kızların ortalama puanları erkek katılımcılardan anlamlı bir şekilde daha yüksektir. Güç değerinde ise erkek katılımcıların puanları anlamlı bir şekilde daha yüksek olarak tespit edilmiştir. Schwartz ve Rubel, erkeklerin güç, uyarılma, hazcılık, başarı ve öz yönelim; kadınların ise iyilikseverlik ve evrenselcilik değer yönelimlerinde daha yüksek ortalama puana sahip olduklarını (Schwartz \& Rubel, 2005, s. 1010); Ulu, öz-yönelim, 
uyarılma, hazcılık, güvenlik, uyma, iyilikseverlik ve evrenselcilikte kadınların; güçte ise erkeklerin ortalama puanlarının anlamlı olarak daha yüksek olduğunu (Ulu, 2018b, s. 205); Cirhinlioğlu ve Şenel, kadınların evrenselcilik ve iyilikseverlikte erkeklerden anlamlı olarak daha yüksek puan elde ettiklerini (Cirhinlioğlu \& Şenel, 2017, s. 316); Emre ve Yapıcı, hazcılık ve uyarılma faktörlerinde erkeklerin daha yüksek puanlar elde ettiklerini, diğer faktörler açısından anlamlı bir farklılaşma olmadığını (Emre \& Yapıcı, 2015, s. 340); Demirutku ve Sümer, erkeklerin güç ve başarı değer yönelimlerinde, kadınların ise evrenselcilikte anlamlı olarak daha yüksek ortalama puana sahip olduklarını (Demirutku \& Sümer, 2010, s. 22); Dilmaç ve diğerleri ise özyönelim, iyilikseverlik, uyma, güvenlik faktörlerinde kız öğrencilerin, hazcılık faktöründe ise erkeklerin yüksek puanlar elde ettiklerini (Dilmaç, Deniz, \& Deniz, 2009, s. 14) tespit etmişlerdir.

Bu sonuçlar göz önüne alındığında bu çalışmanın ulaştığı sonuçlar ile tutarlı bir biçimde kadınların genel itibariyle iyilikseverlik ve evrenselcilik değer yönelimlerinde erkeklerden anlamlı bir biçimde daha yüksek puan aldıkları, yine erkeklerin de genel olarak güç değerinde kadınlardan anlamlı bir biçimde yüksek puana ulaştıkları görülmektedir. Toplumsal cinsiyet rolleri ve toplumun cinsiyetlerden beklentileri göz önüne alındığında bu sonuçlara ulaşılması beklenen bir durum olduğu düşünülmektedir. Kadın ve erkeklerde görülen değer yönelimi farklılıklarında sosyal olarak öğrenilen kadın ve erkek rollerinin etkili olarak bir takım değer yönelimlerinin kadınlarda diğerlerinin de erkeklerde daha fazla öne çıkmalarının olası olduğu, bunun da söz konusu farklılaşmayı anlamlandırma konusunda katkı sağlayabileceği söylenebilir.

Çalışmada ele alınan değişkenler arasındaki ilişkiler ele alındığında hayatın amacı ölçeği toplam puanı ile güç dışındaki başarı, hazcılık, uyarııma, öz-yönlendirme, evrenselcilik, iyilikseverlik, geleneksellik, uyma, güvenlik değerleri arasında güçlü bir ilişki olduğu görülmektedir. Bu bulguların, Frankl'ın hayatın anlamını bulma konusunda yaratıcı, deneyimsel ve tutumsal değerlerin insana yol gösterdiği düşüncesiyle uygunluk arz ettikleri 
söylenebilir. Frankl'a göre bunlardan yaratıcı olanlar sorumluluk duygusuyla bir görevi yerine getirmek için çalışmak ile deneyimsel olanlar karşılaşma ve tecrübe etme yoluyla insan varlığının özsel gerçekliği olan sevgi ile ve tutumsal olanlar ise zorlu durumlarda cesaretle katlanılan acı ile özdeşleştirilir (Forsyth, 2017, s. 332). Görüldüğü üzere Frankl'ın anlama ulaşma veya keşfetmede insana yol gösterdiğini söylediği olgular esas itibariyle bu çalışmada da hayatın anlam ve amacı ile güçlü bir ilişkisi olduğu görülen başarı, evrenselcilik, iyilikseverlik, uyma, uyarılma, öz-yönelim gibi değerleri oluşturan alt bileşenlerdir. Yine değer yönelimi ölçeği toplam puanı ile de hayat kalitesi, anlam ve amaç, özgürlük olmak üzere hayatın amacı ölçeğinin her faktörü ile güçlü bir ilişki tespit edilmiştir. Buna göre, değerler ile hayatın anlam ve amacı arasında güçlü bir ilişki bulunduğu görülmektedir. Söz konusu edilen bulgulardan hareket edilirse, değer yönelimleri güçlü olan insanların hayatta anlam ve amaç bulmakta daha başarılı oldukları, yine hayatta anlam ve amaç sahibi olan insanların da güçlü değer yönelimlerinin bulundukları söylenebilir.

Hangi değer yönelimlerinin hayatın amacındaki varyansı anlamlı bir şekilde açıkladığını incelemek amacıyla yapılan regresyon analizi sonucunda güç, hazcılık, geleneksellik ve güvenlik değer yönelimlerinin hayatın amacını anlamlı bir biçimde açıkladığı tespit edilmiştir. Bahsi geçen dört değer yönelimi hayatın amacındaki varyansın \%13'ünü açıklamaktadır. Bulgulara göre hazcılık, geleneksellik ve güvenlik puanlarındaki artış, hayatın anlam ve amacını bulmaya olumlu manada katkı sağlarken; güç puanındaki artış hayatın anlam ve amacını olumsuz manada etkilemektedir. Bu değer yönelimlerinden hayatın amacı üzerinde en fazla olumlu etkiye sahip olan faktör güvenliktir, daha sonra sırayla geleneksellik ve hazcılık faktörleri gelmektedir.

Araştırma neticesinde ulaşılan bulgulardan hareketle aşağıdaki öneriler söz konusu edilebilir: 
Bu çalışma, Kayseri ilinde öğrenim gören üç devlet lisesinin öğrencileri ile yapılmıştır. Bu araştırmanın değişik şehirlerde öğrenim gören lise öğrencileriyle tekrarlanması araştırma sonuçları hakkında daha güçlü yorumlar yapılabilmesine katkı sağlayacağı için yararlı olacağı düşünülmektedir.

Türkçe literatürde değerlerle ilgili araştırmalar belli bir ölçüde yaygınlık arz etse de hayatın anlam amacı ile ilgili çalışmaların oldukça sınırlı oldukları görülmektedir. Hayatın anlam ve amacının sadece değer yönelimleri ile ilişkilendirilebilecek bir konu olmadığı göz önüne alındığında konuyla ilgili yeni çalışmalar olgunun daha ayrıntılı anlaşıımasına katkı sağlayacağı söylenebilir.

$\mathrm{Bu}$ araştırmanın örneklemin lisede öğrenim gören öğrenciler olduğu düşünüldüğünde belli bir yaş grubu ile sınırlı olduğu görülmektedir. Dolayısıyla elde edilen bulguların diğer yaş veya meslek gruplarına genellenmesi mümkün değildir. Benzer çalışmaların diğer yaş grupları ve meslek gruplarında yapılmasının konuyla ilgili daha kapsamlı bilgi sahibi olunmasına katkı sağlayacağı düşünülmektedir.

\section{Kaynakça}

Adler, A. (2016). Yaşamın Anlam ve Amacı. (K. Şipal, Çev.) (12. bs). İstanbul: Say Yayınları.

Akıncı, A. (2005). Hayata Anlam Vermede Dinî Değerlerin ve Din Öğretiminin Rolü. Değerler Eğitimi Dergisi, 7-24.

Allport, G. W. (2016). Birey ve Dini. (B. Sambur, Çev.) (3. bs). Ankara: Elis Yayınları.

Altun, R. (2015). Fen Lisesi ve İmam Hatip Lisesi Öğrencilerinin Değer Yönelimleri (Samsun Örneği). Gazi Osman Paşa Üniversitesi Illahiyat Fakültesi Dergisi, 3(2), 195-224. 
Arslan, M., \& Tunç, E. (2013). İlahiyat Fakültesi Öğrencilerinin Değer Yönelimlerindeki Farklılaşmalar. Değerler Eğitimi Dergisi, 11(26), 7-39.

Ayvalıoğlu, N. (1989). A Comparison of Turksih and American Value Systems. İstanbul Üniversitesi Tecrübî Psikoloji Çalışmaları, 17, 85-100.

Bahadır, A. (2011). Insanın Anlam Arayışı ve Din. İstanbul: İnsan Yayınları.

Bahadır, A. (2000). Hayatın Anlam Kazanmasında Psiko-Sosyal Faktörler ve Din. Selçuk Üniversitesi Sosyal Bilimler Enstitüsü Dergisi, (6), 185-230.

Baş, V. (2014). Üniversite Öğrencilerinde Değerler ve Yaşamın Anlamı Arasındaki İlişki. Necmettin Erbakan Üniversitesi, Yayınlanmamış.

Baş, V., \& Hamarta, E. (2015). Üniversite Öğrencilerinde Değerler ve Yaşamın Anlamı Arasındaki İlişki. Değerler Eğitimi Dergisi, 13(29), 369391.

Budak, S. (2017). Psikoloji Sözlüğü (5. bs). Ankara: Bilim Ve Sanat Yayınları.

Cirhinlioğlu, F. G., \& Şenel, A. F. (2017). Kadına İlişkin Namus Anlayışı, Değerler ve Cinsiyet Rolleri Arasındaki İlişki. The Journal of Academic Social Science $\quad$ Studies, 311-324. https://doi.org/10.9761/JASSS7213

Ćufta, M. (2016). Yaşlılık Döneminde Hayatın Anlam Arayışı. Pamukkale Üniversitesi İlahiyat Fakültesi Dergisi, (6), 106-116.

Çapcıoğlu, İ., \& Yürük, T. (2011). Modern Dünyada İnsanın Anlam Arayışına Teolojik Katkı: Hz. İbrahim Kıssası Örneği. Modernleşen Türkiye'de Din ve Toplum: Din, Bilgi ve Kültür Sosyolojisi Yazıları, 61-76.

Demirutku, K., \& Sümer, N. (2010). Temel Değerlerin Ölçümü: Portre Değerler Anketinin Türkçe Uyarlaması. Türk Psikoloji Yazıları, 13(25), 17-25. 
Dilmaç, B., Deniz, M., \& Deniz, M. E. (2009). Üniversite Öğrencilerinin ÖzAnlayışları İle Değer Tercihlerinin İncelenmesi. Değerler Eğitimi Dergisi, 7(18), 9-24.

Emre, Y., \& Yapıcı, A. (2015). Kuzey Kıbrıs Türk Cumhuriyeti Vatandaşlarının Değer Yönelimleri. Journal of Turkish Studies, 10(Volume 10 Issue 2), 329-350. https://doi.org/10.7827/TurkishStudies.7764

Erikson, E. (1968). Identity: Youth and Crisis. New York \& London: W. W. Norton \& Company.

Forsyth, J. (2017). Psikolojik Din Kuramları. (M. Ulu, Ed.). Kayseri: Kimlik Yayınları.

Frankl, V. E. (2014). Psikoterapi ve Din. (Z. Taşkın, Çev.). İstanbul: Say Yayınları.

Frankl, V. E. (2016). Insanın Anlam Arayışı. (S. Budak, Çev.). İstanbul: Okuyan Us Yayıncılık.

Hançerlioğlu, O. (1993). Ruhbilim Sözlüğü. İstanbul: Remzi Kitabevi.

Hökelekli, H. (2016). Çocuk, Genç, Aile Psikolojisi ve Din (2. bs). İstanbul: Değerler Eğitimi Merkezi Yayınları.

Karaca, R. (2008). Illahiyat Fakültesi Öğrencilerinin Değer Yönelimleri (Yüksek Lisans). Marmara Üniversitesi, Yayınlanmamış.

Kartopu, S. (2013). Dini Yaşayışta Hayatı Sorgulama ve Anlam Arayışı. Gümüşhane Üniversitesi İlahiyat Fakültesi Dergisi, 2(3), 67-90.

Kıran, Ö. (2016). Üniversite Öğrencilerinin Değer Yönelimleri (OMÜ Örneği). Journal of International Social Research, 9(43), 1266-1266. https://doi.org/10.17719/jisr.20164317695

Kızılgeçit, M., Acuner, H. Y., \& Toklu, G. (2015). İlahiyat Fakültesi Öğrencilerinin Değer Yönelimleri ve Dindarlık-Değer İlişkisi (Rize 
Örneği). Recep Tayyip Erdoğan Üniversitesi Illahiyat Fakültesi Dergisi, (8), 43-84.

Kıraç, F. (2015). Hayatın Amacı Ölçeğinin Psikometrik Özellikleri: Faktör Yapısı ve Güvenilirliği. Uluslararası Sosyal Araştırmalar Dergisi, (39), 490-500.

Mehmedoğlu, A. U. (2016). İlâhiyat Fakültesi Öğrencilerinin Değer Yönelimleri ve Dindarlık-Değer İlişkisi (M.Ü. İlâhiyat Fakültesi Örneği). Marmara Üniversitesi Illahiyat Fakültesi Dergis, (30), 133-167.

Özarslan, S. (2000). Ahiret İnancının İnsanın Anlam Arayışına Müspet Katkısı. Fırat Üniversitesi İlahiyat Fakültesi Dergisi, (5), 295-307.

Özcan, Z., \& Erol, H. K. (2017). Üniversite Öğrencilerinin Değer Yönelimleri ve Dindarlık-Değer İlişkisi (Karabük Örneği) / Tendency of University Students towards Values and Relation of Religiousness \& Values (Sample of Karabuk). Journal of History Culture and Art Research, 6(4), 913. https://doi.org/10.7596/taksad.v6i4.1091

Özdoğan, Ö. (2005). İsimsiz Hayatlar (2. bs). Ankara: Lotus Yayınevi.

Reker, G. T., \& Wong, P. T. P. (1983). Aging As an Individual Process: Toward a Theory of Personal Meaning. Içinde J. E. Birren \& V. L. Bengtson (Ed.), Emergent Theories of Aging. New York: Springer Publishing Company.

Rokeach, M. (1973). The Nature Of Human Values. New York: Free Press.

Roszkowski, M. J., Kinzler, R. J., \& Kane, J. (2014). Profile of a Residential Learning Community on Schwartz's Typology of Values. Journal of Service-Learning in Higher Education, 3, 5-29.

Schwartz, S. H. (1992). Universals in the Content and Structure of Values: Theoretical Advances and Empirical Tests in 20 Countries. Içinde 
Advances in Experimental Social Psychology (C. 25, ss. 1-65).

Academic Press. https://doi.org/10.1016/S0065-2601(08)60281-6

Schwartz, S. H. (1994). Are There Universal Aspects in the Structure and Contents of Human Values? Journal of Social Issues, 50(4), 19-45. https://doi.org/10.1111/j.1540-4560.1994.tb01196.x

Schwartz, S. H., \& Bilsky, W. (1987). Toward A Universal Psychological Structure of Human Values. Journal of Personality and Social Psychology, 550-562.

Schwartz, S. H., Melech, G., Lehmann, A., Burgess, S., Harris, M., \& Owens, V. (2001). Extending the Cross-Cultural Validity of the Theory of Basic Human Values with a Different Method of Measurement. Journal of Cross-Cultural Psychology, 32(5), 519-542. https://doi.org/10.1177/0022022101032005001

Schwartz, S. H., \& Rubel, T. (2005). Sex Differences in Value Priorities: Cross-Cultural and Multimethod Studies. Journal of Personality and Social Psychology, 89(6), 1010-1028. https://doi.org/10.1037/00223514.89.6.1010

Selçuk, M. (1998). İnsanın Anlam Arayışı ve Vahiy. Içinde İslam'ın Işığında Kadın. Ankara: Türkiye Diyanet Vakfı Yayın Matbaacılık Ve Ticaret İşletmesi.

Serinsu, A. N. (2012). Kur'an İnsanın Anlam Arayışına Cevaptır. Diyanet İlmi Dergi, (Kur'an Özel Sayısı), 707-719.

Sezen, A. (2009). Günümüz İnsanının Anlamsızlık Sorunu Bağlamında Frankl ve Fowler'da Bireyin Anlam Arayışı. Sosyal Bilimler Araştırma Dergisi, 7(14), 189-201.

Smith, P. B., \& Schwartz, S. H. (1997). Values. Içinde J. W. Berry, M. H. Segall, \& Ç. Kağıtçıbaşı (Ed.), Handbook of Cross-Cultural Psychology (C. 3, ss. 77-118). Boston: Allyn and Bacon. 
Türk Dil Kurumu. (t.y.). Geliş tarihi 08 Ekim 2018, gönderen http://www.tdk.gov.tr/index.php?option=com_gts\&arama=gts\&guid=TD K.GTS.5bbb2caf315f82.37160051

Ulu, M. (2018a). Hayatı Anlamlandırma ile Kişilik Özellikleri Arasındaki İlişki Üzerine. Bilimname, (36), 165-188. https://doi.org/10.28949/bilimname.459247

Ulu, M. (2018b). İlahiyat Fakültesi Öğrencilerinin Psikolojik İyi Oluşları İle Değer Yönelimleri Arasındaki İlişki. Sakarya Üniversitesi İlahiyat Fakültesi Dergisi 183-215. https://doi.org/10.17335/sakaifd.414012

VandenBos, G. R., \& American Psychological Association (Ed.). (2015). APA Dictionary of Psychology (Second Edition). Washington, DC: American Psychological Association.

Yapıcı, A., Kutlu, M. O., \& Bilican, F. I. (2014). Öğretmen Adaylarının Değer Yönelimleri. Elektronik Sosyal Bilimler Dergisi, 11(42), 129-151. 


\section{The Relationship Between Meaning and Purpose of Life and Value Orientations in High School Students}

Citation / @-- Tanrıverdi, A. ve Ulu, M. (2018). The Relationship Between Meaning and Purpose of Life and Value Orientations in High School Students, Cukurova University Journal of Faculty of Divinity 18 (2), 1198-1234.

Abstract- The theoretical framework of this study is based on the views of Viktor Emil Frankl on the meaning and purpose of life, based on the idea that human's main motive is the desire of meaning, and the approaches of Shalom $\mathrm{H}$. Schwartz on the value orientation.

The aim of this study is to examine the relationship between the meaning and purpose of life and value orientations in high school students. In the study, 507 students studying in 3 different state high schools in Kayseri were chosen by quantitative method. Participants were selected from random sampling methods by "convenient / easy sampling method". 30\% ( $n=150)$ of the participants were male and $70 \%(n=357)$ were female students. The data were collected by the Purpose of Life Scale developed by Crumbaugh and Maholick, adapted by Ferdi Kıraç to Turkish and by the Portrait Values Questionnaire, which was developed by Schwartz et al. and adapted to Turkish by Demirutku and Sumer. Mean and standard deviation values from descriptive statistical techniques in the analysis of data; independent $t$-test of inferential statistical techniques; Pearson Moments Multiplication Correlation technique and Regression analysis are used. According to the results of the analysis, the average score of the participants in the value orientation was 4.63; the mean score of purpose of life was 3.40; the highest score of value orientation was self-direction (4.94), and the lowest score of value orientation was power (3.90); in the Purpose of Life Scale the highest score was 3.89 in mean and purpose factor and the lowest score was was 2.91 in life quality factor. In addition, the average score of girls in benevolence and universalism and in men in the power factor were significantly higher; a positive relationship between the Purpose of Life Scale and achievement, hedonism, arousal, self-directedness, universalism, benevolence, traditionalism, conformity, security values; and the Portrait Values Questionnaire total score showed a strong positive relationship between all factors on the purpose of life scale. As a result of the regression analysis, it is seen that power, hedonism, traditionalism, and security value orientations significantly explain the purpose of life by level of $13 \%$.

Keywords- Meaning and purpose, logotherapy, value orientation, high school 